\title{
THE USE OF CHILD SOLDIERS IN ARMED CONFLICT
}

\author{
Kearen Bell \\ LLB
}

Candidate Attorney, Goldberg \& De Villiers Inc

David Abrahams

BJuris LLB LLM LLM

Lecturer in Law

Nelson Mandela Metropolitan University

Port Elizabeth

\section{SUMMARY}

The use of the child soldier is by its very nature contradictory. It is therefore not surprising that the law pertaining to and providing protection for the child soldier is uncertain and often vague.

The object of this article is to analyse the use of child soldiers in armed conflict, so as to ascertain the complete situation surrounding the child soldier. The relevance of such an examination lies in the fact that the continued dissemination and awareness of this situation will ensure that further preventative and protective measures are taken, thereby ensuring that the rights of the child soldier are afforded and implemented in a manner consistent with the child's best interests.

The first part of this article serves essentially as a prologue, defining a "child soldier" and highlighting the context in which the analysis of the use of child soldiers will occur. The second part exposes the consequences of participation in armed conflict, whilst exploring some of the encouraging factors of war which contribute to the emergence of the phenomenon of child soldiering.

In law regarding to the child soldier is both analysed and ascertained next, whereafter the full legal position in regard to the child soldier is obtained through the consideration of customary international law.

The penultimate part of this article deals with the enforcement and implementation of the law pertaining to the child soldier. The relevance of NGOs and international humanitarian organisations is considered, and recommendations posed by the ICRC are referenced. The conclusion serves to condense the findings of this article, so as to ensure concisely that the full position in relation to the child soldier in armed conflict becomes apparent.

\section{INTRODUCTION}

The Universal Declaration of Human Rights ${ }^{1}$ recognises that the status of childhood is deserving of special care and affection. ${ }^{2}$ This position is

\footnotetext{
Universal Declaration of Human Rights of 10 December 1948.
}

Declaration of Human Rights article 25(2). 
reiterated in a number of international treaties ${ }^{3}$ and municipal instruments. ${ }^{4}$ The special care and protection afforded to the child are based on his lesser developed psychological and physical well-being, making him a particularly vulnerable category of person. The special protection enjoyed by the child is not limited to peacetime and this protection has been extended to him in times of armed conflict. In particular special protection has been afforded to the child combatant through international humanitarian law.

The phenomenon of child combatants has become known in a world where democracies are allegedly secured and the affordance of basic human rights is valued. The employment of this term into our vocabulary suggests that a gross violation of basic children's rights continues. This violation manifests in the most vulnerable and weak: the war-ravaged children of a country in conflict.

It was not until 1977, the year in which the Protocols Additional to the Geneva Conventions ${ }^{5}$ were adopted, that the term "combatant" was defined. ${ }^{6}$ A combatant is defined in Article 43(2) of Additional Protocol $\mathrm{I}^{7}$ as being:

"Members of the armed forces of a Party to a conflict (other than medical personnel and chaplains covered by article 33 of the Third Convention) are combatants, that is to say, they have the right to participate directly in hostilities."

A child is defined under international human rights law as: "Every human being below the age of eighteen years unless under the law applicable to the child, majority is attained earlier", ${ }^{8}$ thereby making eighteen the age at which majority status is acquired internationally.

Upon reaching the age of fifteen a child may be recruited for service as a combatant in armed forces which are at conflict. ${ }^{9}$ An inference can then be drawn that under international human rights law, a child combatant is regarded as any person under the age of eighteen but above the age of fifteen, who is a member of armed forces party to a conflict.

United Nations Convention on the Rights of the Child of 1989 for example, reiterates this position in its preamble.

4 Constitution of the Republic of South Africa, 1996 is an example of municipal law which renders specific protection to children and is evident in article 2(28) of the Constitution.

5 Protocol Additional to the Geneva Conventions of 12 August 1949, and Relating to the Protection of Victims of International Armed Conflicts (Protocol I) of 8 June 1977, and Protocol Additional to the Geneva Conventions of 12 August 1949, and Relating to the Protection of Victims of Non-International Armed Conflicts (Protocol II) of 8 June 1977. (hereinafter referred to as AP I or AP II respectively).

6 Haug Humanity for All (1993) 512.

AP I article 43(2).

United Nations Convention on the Rights of the Child of 1989 article 1.

9 United Nations Convention on the Rights of the Child of 1989 article 38. 
In a number of countries the age of majority is deemed to be twenty-one. ${ }^{10}$ A number of international humanitarian law and regional instruments regard eighteen as the minimum age for recruitment into armed forces. ${ }^{11}$

The conflicting provisions contained within the various legal instruments dealing with child combatants create legal uncertainty and will ultimately result in further injustice for the child.

The threat that is posed by this legal uncertainty has resulted in a number of conflicting legal provisions and practices relating to the use of child combatants above and below a certain age. This conflict ultimately clouds the issue at hand; that being the provision of maximum protection for children and ensuring that the child's best interests are given due consideration.

The importance of the phenomenon of the child combatant cannot be underestimated and the more light that is shed on this matter, the better the position will be for children who have become party to and are still to become victims of war. The effective and continued communication dealing with the status of a child and especially a child soldier is vitally important, because it is only once the problems surrounding this phenomenon have been recognised and the proposed solutions identified, that effective measures can be taken to counter the negative effects of war on child soldiers and minimise the long-term damage caused by war.

The focus of this paper will be on an analysis of the general position surrounding the child soldier in times of armed conflict. Reference will be made to the general and specific consequences of hostilities on a child soldier, with particular attention being devoted to the ascertainment of the legal position pertaining to the child soldier.

For purposes of this topic, the terms "child combatant" and "child soldier" will be used interchangeably and they will appear in the exact format as derived from the authorities referenced.

\section{THE EFFECTS OF HOSTILITIES ON A CHILD SOLDIER}

\section{Reasons behind "voluntary" participation in armed conflict}

The consequences of a war on a community can be catastrophic, resulting in broken homes, no access to schools and increased poverty to name but a

10 In South Africa, the Age of Majority Act 57 of 1972 has recently been amended to reduce the age of majority to eighteen.

11 The African Charter on the Rights and Welfare of the Child article 22 and Optional Protocol to the Convention on the Rights of the Child on the involvement of children in armed conflict: A/RES/54/263 of 25 May 2000. 
few, and joining the army is often perceived to be a child combatant's greatest chance at survival. ${ }^{12}$

Much research has been conducted surrounding the reasons behind the voluntary participation of child soldiers into armed forces. The research undertaken by Rachel Brett, ${ }^{13}$ a representative of the United Nations office at Geneva, served to show that, based on qualitative research involving interviews with former child soldiers who had "voluntarily" participated in armed conflict, there exist inter alia five consistent factors influencing children to become voluntary combatants.

These factors are war, poverty, education, employment and family, ${ }^{14}$ and each one will be separately dealt with below.

\section{War}

War, as obvious as it may sound, is in itself a contributing factor to the creation of child soldiers. ${ }^{15}$ The occurrence of war is thought of not only as invading the lives of children, but also as creating an opportunity. The opportunities created by war are opportunities for employment, escape from oppressive family or school situations, a chance to emulate military role models or to join the family tradition of fighting and the opportunity to serve a cause; whether political, religious or ethnic. ${ }^{16}$

A continuous state of war in a country clearly exacerbates the other factors contributing to the phenomenon of child soldiers and the creation of further reasons for joining the war, such as the need for self-protection. ${ }^{17}$

\section{Poverty}

Poverty has been identified as the single largest motivational factor behind voluntary participation in armed conflict and this is the most common characteristic shared by child soldiers. ${ }^{18}$

War is deemed to be a further aggravation of poverty as families become dispersed; breadwinners join the armies whilst others are killed and schools and businesses close, thus causing increased unemployment rates.

\footnotetext{
"Stop the Use of Child Soldiers!" http://www.hrw.org/campaigns/crp/index.htm (accessed 2006-05-08).

3 Brett "Adolescents Volunteering for Armed Forces or Armed Groups" 2003 International Review of the Red Cross (hereinafter referred to as the "IRRC") 857.

4 Brett 2003 IRRC 859

15 lbid.

Ibid.

Ibid.

Brett 2003 IRRC 860.
} 


\section{Education}

The often limited access to schools and the ability to obtain an education is an important consideration when deciding to join the army voluntarily.

Even in situations where an education is available at a school, children will often drop out if their prospects of finding employment seem less certain than a career with the army. Further factors to consider when dealing with education as a contributor to the creation of child soldiers are both peer influence within the schools, and the fact that such children may have been excluded from the schooling system for personal reasons such as bad behaviour. $^{19}$

The lack of education in war-ravaged countries further lessens the prospects of finding employment and therefore a means of survival. The army, however, is one of the few employers that do not require any qualifications and this contributes greatly as a motivator for joining the army. $^{20}$

It is also interesting to note that many schools act as a base from which military recruitment occurs. ${ }^{21}$

\section{Employment}

Poverty, education and employment all seem to go hand in hand and they are the most obvious consequences of war on a country. The scarcity of jobs and the limited or seemingly insufficient education for purposes of finding employment are motivators to join armed forces.

The need for employment directly translates to the need for financial support for the child's well-being and in many cases, for his entire family.

\section{Family}

The influence of a child's family to become a member of an armed force is another crucial factor. The displacement and in some cases death of family members create a gap in the family and often children are left to fend for themselves.

The influence of family is regarded as another large contributing factor to the cause of child combatants in that it is particularly prevalent in homes where children were a part of an abusive or potentially abusive family.

The tendency of children who have come from a military family to partake in armed conflict, especially boys, is a common one. ${ }^{22}$

\footnotetext{
Brett 2003 IRRC 861.

Brett 2003 IRRC 860

Ibid.

Brett 2003 IRRC 862.
} 
Another important contributor to the phenomenon of child soldiers is one of self-defence. Self-defence was mentioned ${ }^{23}$ as a contributory factor on a number of occasions, and in most instances was cited as the cause of their participation in armed conflict.

\section{The debate surrounding "voluntary" participation}

It is well known that children are forced through abduction, prescription and coercion by "press-ganging" ${ }^{24}$ to become combatants in armed conflict. There are, however, a number of children who voluntarily participate in armed conflict ${ }^{25}$ for various reasons, some of which are listed above.

The relevance of a brief analysis into "voluntary" participation in armed conflict by children is done so as to explore what voluntary participation actually entails and lists the circumstances under which voluntary participation by children is valid, where it normally would not be so.

In the study undertaken by Rachel Brett, ${ }^{26}$ a number of former child soldiers were interviewed who had identified themselves as voluntary participants in war, and it became evident that many children were actually volunteers through necessity or by coercion through fear. A child combatant from Sierra Leone cited the following as his reason for voluntarily electing to join the army:

"One of my friends ... was shot in the head because he refused to join them.

He was killed straight in front of me."

It also became apparent that the term "voluntary" was misunderstood, as were the implications of becoming a militant in a war.

Further consideration must be given to the term "voluntary" as it creates some pertinent legal questions. ${ }^{28}$ The concept of "voluntary" participation by children is only defined in one legal instrument, namely the Optional Protocol, ${ }^{29}$ which has only been ratified by 122 countries. ${ }^{30}$ The Optional Protocol lays down four minimum safeguards to be complied with when State Parties permit voluntary recruitment into their armed forces below the age of eighteen.

These are that:

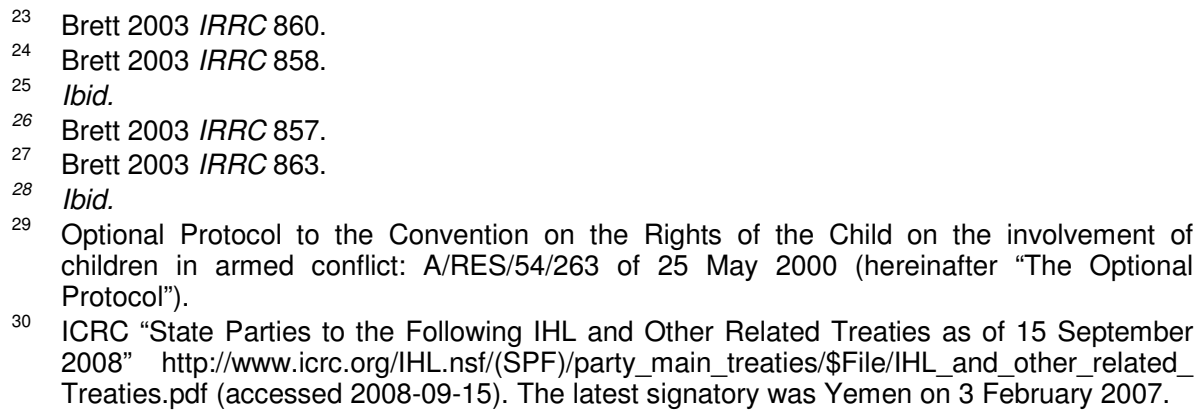

30 ICRC "State Parties to the Following IHL and Other Related Treaties as of 15 September 2008" http://www.icrc.org/IHL.nsf/(SPF)/party main treaties/\$File/IHL and other related Treaties.pdf (accessed 2008-09-15). The latest signatory was Yemen on 3 February 2007. 
"(a) Such recruitment is genuinely voluntary;

(b) Such recruitment is carried out with the informed consent of the person's parents or legal guardians;

(c) Such persons are fully informed of the duties involved in such military service;

(d) Such persons provide reliable proof of age prior to acceptance into national military service."

In light of these safeguards, many children would not fall into the category of volunteers at all. The legal debate surrounding the true distinction between voluntary and compulsory recruitment is important in assisting children with demobilization and reintegration into society. ${ }^{32}$ The relevance of this is psychologically based. ${ }^{33}$

The pull-factors for recruitment into armies are particularly relevant in the context of voluntary participation, but attention must also be drawn to the fact that voluntary participation in armed conflict is perhaps a misnomer in that it creates the perception that there is a willingness to play a part in a war. Bearing in mind the atrocities associated with war it should be an absurd concept to have voluntary participation allowed in a war where the participation is based on intrigue, societal pressure or circumstance.

\section{Physical and psychological effects of participation in armed conflict}

The few personal accounts which have been included below are imperative in order that justice to this very significant topic be duly given. There are very few people, including leaders of armed forces and groups, who fully understand and grasp the severity of the impact of war on a child combatant, and the more awareness that exists around this topic the better, as it may force and strengthen the campaign against the use of child soldiers. Below are a few brief but insightful glances into the minds of child combatant victims:

P.K., now 13, was abducted in Liberia in 2002:

"Government soldiers came and forced me and my father to join them. My father refused so they cut his throat. They beat me and tied me and forced me to join the fighters.

A Peruvian woman who was recruited by the Shining Path at age 11:

"They beat all the people there, old and young, they killed them all, nearly 10 people ... like dogs they killed them ... I didn't kill anyone, but I saw them killing ... the children who were with them killed too ... with weapons ... they

The Optional Protocol article 3(3).

Brett 2003 IRRC 863.

Ibid.

34 "Childhood Denied: Child Soldiers in Africa" http://web.amnesty.org/pages/childsoldiersafricanchild-eng\#top\#top (accessed 2006-05-06). 
made us drink the blood of people, we took blood from the dead into a bowl and they made us drink ... then when they killed the people they made us eat their liver, their heart, which they took out and sliced and fried ... And they made us little one[s] eat."

Albert was 15 when he was recruited by an armed opposition group in the Democratic Republic of Congo (DRC):

"[T]hey would give us 'chanvre' [cannabis] and force us to kill people to toughen us up. Sometimes they brought us women and girls to rape ... They would beat us if we refused."

A 13-year old former child soldier from Liberia said:

"They gave me pills that made me crazy. When the craziness got in my head, I beat people on their heads and hurt them until they bled. When the craziness got out of my head I felt guilty. If I remembered the person I went to them and apologized. If they did not accept my apology, I felt bad."

These are just a few accounts, amongst many tens of thousands, which briefly touch upon the violence encountered daily by child combatants. This miniscule exposure into the experience of a few child combatants forces the realisation of the dire situation that these children find themselves in and the permanent and often debilitating effects that war is accompanied by.

The lack of experience and immaturity of child soldiers ensures that they are the victims of greater casualties than their adult counterparts. ${ }^{38}$ Child combatants who have not undergone any rehabilitation or have been subjected to improper rehabilitation may struggle with a peaceful reintegration into society, and having been schooled exclusively in war this often results in their turning to crime and violence.

\section{INTERNATIONAL LAW APPLICABLE TO CHILD COMBATANTS}

\section{International Human Rights Law $v$ International Humanitarian Law}

Human rights are the basic rights that every human being is entitled to by virtue of his or her mere existence. ${ }^{39}$ Human rights are entrenched in both

35 "Stop the Use of Child Soldiers!" http://www.hrw.org/campaigns/crp/index.htm (accessed 2006-05-08).

36 "Childhood Denied: Child Soldiers in Africa" http://web.amnesty.org/pages/childsoldiersafricanchild-eng\#top\#top (accessed 2006-05-06).

37 Ibid.

38 "Stop the Use of Child Soldiers!" http://www.hrw.org/campaigns/crp/index.htm (accessed 2006-05-08).

39 Ang Article 38 Children in Armed Conflicts: A Commentary on the United Nations Convention on the Rights of the Child (2005) 9. 
international and regional instruments worldwide, making their applicability universal and subjective. ${ }^{40}$

International humanitarian law is that branch of international law which governs situations of armed conflict. ${ }^{41} \mathrm{IHL}$ has its origins in either international customary law or treaty, and it was established with the intention of solving the humanitarian issues which arose directly from either international or non-international armed conflicts. ${ }^{42}$ The role of IHL is to offer protection to persons and to property which may be affected by an armed conflict. ${ }^{43} \mathrm{IHL}$ is therefore the body of law which inter alia regulates the law pertaining to child combatants.

Both human rights law and IHL have an important role to play when analysing the position of child combatants in times of armed conflict.

The fundamental guarantees afforded to children under human rights law elevate the status of a child into a class of their own, thus affording them very specific rights which are codified and entrenched. Human rights law has general applicability during both peace and wartime, making it a priority consideration in respect of the rights pertaining to the child combatant.

\section{International law applicable to child combatants}

The fundamental guarantees which a child is afforded can be found in a number of international covenants, the most important of which are listed and discussed below.

\section{The United Nations Convention on the Rights of the Child $^{44}$}

The Convention on the Rights of the Child is an important one for purposes of witnessing the special protection afforded internationally to children. This Convention has been ratified by every State but the United States and Somalia, ${ }^{45}$ making it hugely influential and important. The preamble to this convention specifically recognises the need for particular precautions and cares to be taken based on a child's physical and mental immaturity. The CRC further states that any legal actions taken by any authority which concern children, must ensure that the best interests of the child are a primary consideration. ${ }^{46}$

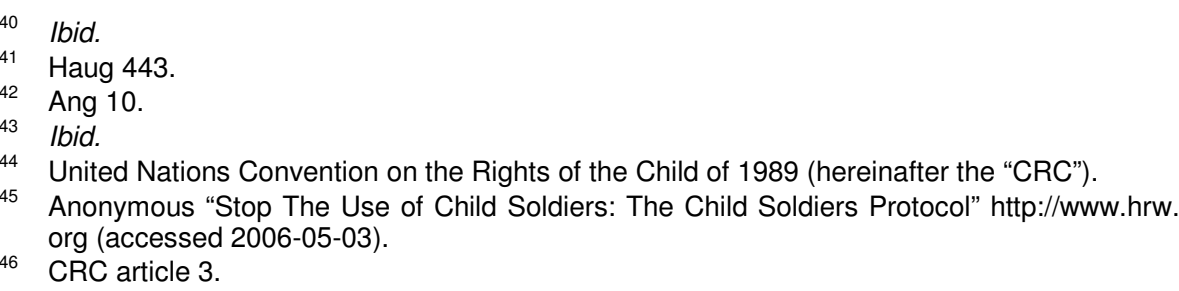


The CRC is hybrid in nature as it is a human rights document ensuring respect for $\mathrm{IHL},{ }^{47}$ which is done through the provision of express protection for child combatants. ${ }^{48}$ An holistic approach to the law is provided for by the unique nature of this convention in that it unites $\mathrm{IHL}$ and human rights law into one document. ${ }^{49}$ The advantage of the CRC is that the child combatant is protected in times of both peace and war.

Article 38 of the convention is clearly an IHL one and support for this statement is reinforced by the typically IHL terminology employed herein. ${ }^{50}$ The structure of this article also reflects an IHL scheme in that its first provision deals generally with the applicability of $\mathrm{IHL}$, the second and third provisions offer protection for children through the imposition of minimum age requirements, whilst the last provision ensures general protection for the civilian population by State Parties to this convention. ${ }^{51}$ Article 38 finds applicability in all types of armed conflict. ${ }^{52}$

The $\mathrm{CRC}$ regards a person below the age of eighteen as being a child, ${ }^{53}$ whilst further provisions stipulate that fifteen is regarded as the earliest age at which either recruitment or direct participation in hostilities be allowed. ${ }^{54}$ The convention also prescribes that when recruitment into armed forces occurs, priority should be given to those children that are oldest. ${ }^{55}$ State Parties to this convention are also obliged to adhere to their IHL obligations and ensure satisfactory protection and care of children who are exposed to armed conflict. ${ }^{56}$ The problem posed by Article 38 is that it is believed to cater more towards the protection of the child civilian than to that of the child combatant. $^{57}$

Through the imposition of a minimum age requirement for when direct participation in hostilities may occur, protection is afforded to the child who is yet to become a combatant, and not to the child who is already a combatant. This provision appears to be of no benefit to child combatants who are already direct participants in an armed conflict. ${ }^{58}$ Article 39 of the CRC obliges State Parties to demobilize child combatants, ${ }^{59}$ thereby compelling State Parties to take appropriate measures aimed at both the social

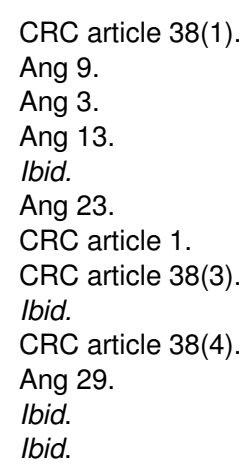


reintegration, and the promotion of the recovery of a child who is a victim of inter alia armed conflict, both physically and psychologically. ${ }^{60}$

The wording used in the CRC actually lowers the minimum standard set down for participation in non-international armed conflicts. ${ }^{61}$ Additional Protocol II prohibits children under the age of fifteen from taking part in hostilities at all, ${ }^{62}$ whereas the CRC merely prohibits direct participation in hostilities. ${ }^{63}$ Therefore, instead of raising the standard of protection for children involved in international armed conflict, the CRC lowers the standard of protection ${ }^{64}$ afforded and in doing so, the best interests of the child have not been given the necessary consideration.

Article 41 of the convention renders Article 38 as inapplicable if State Parties are bound by another, stronger international obligation. ${ }^{65}$ The effect of this article will then be to ensure that State Parties to the convention provide the most conducive protection for the child, in accordance with their respective international obligations. ${ }^{66}$

The relevance of the CRC lies in its hybrid nature. ${ }^{67}$ The fact that this human rights law document encompasses $\mathrm{IHL}$ is an important step forward for the protection of child combatants and the incorporation of $\mathrm{IHL}$ into human rights law will ensure that the CRC Committee is able to address the gaps that exist between law and practice. ${ }^{68}$

\section{Protocols Additional to the Geneva Conventions ${ }^{69}$}

Both of the Additional Protocols to the Geneva Conventions are significant $\mathrm{IHL}$ instruments. Each protocol has been ratified by more than 150 countries ${ }^{70}$ thereby ensuring that they enjoy a widespread application.

Additional Protocol I, which deals with armed conflicts of an international nature ${ }^{71}$ states that children should be the object of special respect and that they should have provision made for their care and aid. ${ }^{72}$ Article $77(2)$ requires that a child reach the age of fifteen before participating directly in hostilities. This provision states further that children below the age of fifteen

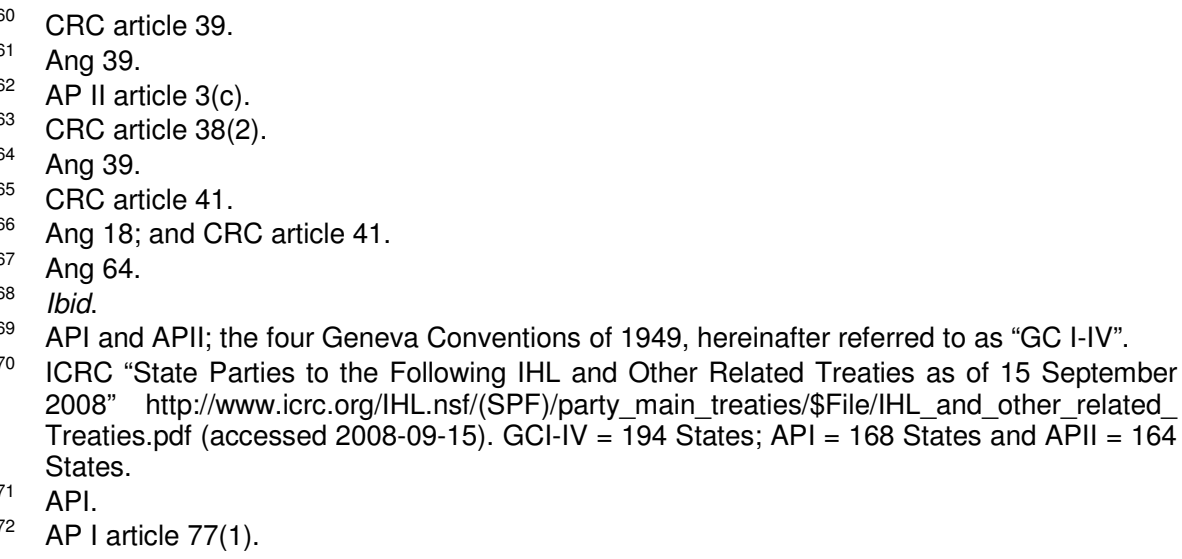


should not be recruited into armed forces. This Article leaves room for confusion.

A literal interpretation of Article 77(2) is that children under the age of fifteen do not participate in armed conflict directly, which suggests that indirect participation is acceptable. The second part of this provision, however, goes further, expressing that State Parties should refrain from recruiting children under the age of fifteen into their armed forces. This part of the provision might then be implying that indirect participation in armed conflict might not be acceptable after all, and this confusion is then reduced to an issue of semantics. The academic debate regarding the exact definition of the term recruiting ${ }^{73}$ hopes to clarify the issue at hand, that being whether the second part of the provision can be thought of as ruling out the inference made in the first part of the provision, which suggests that indirect participation in armed conflict is allowed. The obligation imposed on State Parties to refrain from recruiting children under the age of fifteen into an armed force suggests that their indirect participation in hostilities might not be allowed.

What does the term "recruitment" then entail? If it intends that this term is only used for compulsory recruitment then it suggests that voluntary recruitment could still occur, thereby still making room for indirect participation but if it encompasses voluntary, compulsory or forced recruitment ${ }^{74}$ then this provision does not in fact distinguish between direct and indirect participation in armed conflict by children under the age of fifteen. A blanket ban on any sort of participation by children under fifteen years old can then be inferred. This, however, is not the case, and this term has been put forward by academics as only incorporating the aspect of compulsory recruitment. ${ }^{75}$ The drafting history of Article $77(2)$ reveals that the International Committee of the Red Cross (ICRC) ${ }^{76}$ had originally incorporated the term "voluntary enrolment" into the provision but had deliberately deleted it from the final version of the Protocol. ${ }^{77}$ This omission has been explained as implying the "exclusively compulsory character", of this Article. In light of this argument, it can then be inferred that Article 77(2) does not in fact provide maximum protection for children in respect of participation and recruitment into armed forces.

Article $77(2)$ establishes the priority rule ${ }^{79}$ which states that when State Parties recruit children who have attained the age of fifteen but not eighteen,

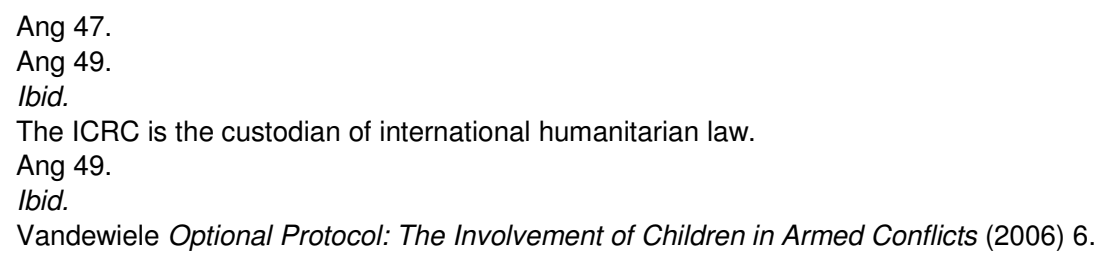


preference should be given to those that are oldest. ${ }^{80}$ This Article is not an absolute one as is evident based on the usage of the term "to endeavor." ${ }^{11}$

A further provision which safeguards against possible loopholes was included in Additional Protocol I. This safeguard guarantees that a child below the age of fifteen who has taken a direct part in hostilities and subsequently fallen into the power of an adverse party, retains the special protection afforded to children above fifteen, irrespective of whether they are prisoners of war or not. ${ }^{82}$

Additional Protocol II regulates non-international armed conflicts. ${ }^{83}$ The protection provided by this protocol is greater than that provided for by AP I. AP II expressly prohibits the participation of children under the age of fifteen from taking part in hostilities. ${ }^{84}$ The fact that the term "directly" has been left out of this Article suggests that any participation in hostilities is banned, be it direct or indirect. This position is clearly inferred from the words employed in this article, namely that:

"children who have not attained the age of fifteen years shall neither be recruited in the armed forces or groups nor allowed to take part in hostilities."

This would mean that AP II provides stronger protection for children in non-international armed conflicts, than AP I provides for children in international armed conflicts.

AP II also contains a "safety-net provision" which ensures that a child under fifteen, who contrary to the provision, is taking an active part in hostilities, will still benefit from the special protection afforded to children under Article 4 . $^{86}$

The role played by the Additional Protocols should not be underestimated, however, as it was through these instruments that the law in regard to the use of child soldiers in armed forces was first adopted. ${ }^{87}$ The fact that prohibitions have been placed on the age for recruitment and participation in hostilities, serves as a platform from whence greater protection of the child combatant can arise.

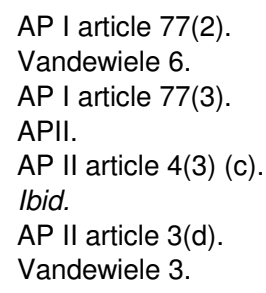




\section{Optional Protocol to the Convention of the Rights of the Child on the Involvement of Children in Armed Conflict t8 $^{88}$}

Generally speaking, the Optional Protocol offers the greatest protection to the position of the child soldier. ${ }^{89}$ The Optional Protocol is a relative newcomer to $\mathrm{IHL}$, only coming into effect on 12 February $2002 .^{90}$

This protocol, as is indicated in its name, deals exclusively with child soldiers in armed conflicts, and it raises the minimum age requirement for direct participation in armed forces to eighteen. ${ }^{91}$ As far as recruitment is concerned, the Protocol raises the minimum age for compulsory recruitment to eighteen, ${ }^{92}$ but allows State Parties to set down their own age requirements in respect of voluntary recruitment. The Protocol does, however, impose a minimum set of requirements to be complied with in cases of voluntary recruitment, namely that the minimum age for voluntary recruitment be raised to sixteen ${ }^{93}$ and that certain standards are complied with, which would validate voluntary involvement. ${ }^{94}$

The Optional Protocol, whilst being an effective milestone in the plight against the use of child soldiers, does not completely protect all children from armed conflict and its consequences. The imposition of eighteen as the minimum age for direct participation in hostilities ${ }^{95}$ is a step forward, as is the imposition of eighteen as the minimum age for compulsory recruitment, ${ }^{96}$ but the exclusion of voluntary recruitment from Article 2 lowers the level of protection once again for children who are volunteers. The actual term "compulsory", which is used in Article 2, poses a problem. The term usually denotes that a person is compelled by force to do something and a clear distinction between "compulsory" and "voluntary" is a difficult one to make. A child might voluntarily join the armed forces because he is coerced into doing so or for some similar reason and in light of this the Optional Protocol appears to be somewhat of an anomaly.

It is interesting to note that the Protocol refers to "persons" under the age of eighteen and not just "children," therefore implying that the Protocol is

88 Optional Protocol to the Convention on the Rights of the Child on the involvement of children in armed conflict: A/RES/54/263 of 25 May 2000.

89 Vandewiele 3

90 Sassoli How does Law Protect in War?: Vol II (2006) 636; and Coalition to Stop the Use of Child Soldiers "International Standards" http://www.child-soldiers.org/resources/international -standards (accessed 03 October 2006).

91 Optional Protocol article 1.

92 Optional Protocol article 2.

93 Optional Protocol article 3(1); and Vandewiele 6.

94 Optional Protocol article 3(3).

95 Optional Protocol article 1.

96 Optional Protocol article 2. 
equally applicable to persons younger than eighteen who have lost their status as children. ${ }^{97}$

The implementation of this Protocol is provided for through the compulsion of State Parties to demobilize children recruited, or who are used in armed conflicts in violation of the provisions of the Protocol. ${ }^{98}$ There also rests a duty on State Parties to ensure that appropriate measures are taken for the rehabilitation and reintegration of such children. ${ }^{99}$

The Optional Protocol has also been criticised for allegedly providing a double standard ${ }^{100}$ for armed forces to a State Party and armed forces not of a State Party. The Protocol states that State Parties should take all "feasible measures" to ensure that under-eighteen's do not take a direct part in hostilities, ${ }^{101}$ whilst armed groups which are distinct from the State "should not, under any circumstances, recruit or use in hostilities persons under the age of eighteen." 102 The ICRC comment on this situation is as follows:

"The ICRC welcomes the fact that the issue of non-state actors has been included in the Optional Protocol, but regrets that the provision imposes a moral, as opposed to a legal obligation. Although Article 4 also provides for criminal prosecution under domestic law, this is likely to be of limited effect, because those who take up arms against the lawful Government of a country already expose themselves to the most severe penalties of domestic law, and because the capacity of a Government to enforce its laws is often very limited in situations of non-international armed conflicts. Third, it is uncertain whether non-state actors will feel bound by a norm which is different from that imposed on States, and thus whether it will be respected ...."

The Optional Protocol in its entirety does raise the level of protection for the child soldier to a greater level than any other Conventions do, and is an important contributor to the law relating to child combatants. Furthermore, the relevance of the Optional Protocol lies in the fact that it enjoys application in conflicts of both an international and a non-international nature. ${ }^{104}$

$97 \quad$ Vandewiele 31.

98 Optional Protocol article 6(3) and Anonymous "Stop The Use of Child Soldiers: The Child Soldiers Protocol" http://www.hrw.org (accessed 2006-05-03).

99 lbid.

100 Anonymous "Human Rights-Theory and Practise" http://www.tamilnation.org (accessed 2006-05-03)

101 Optional Protocol article 1.

102 Optional Protocol article 4.

103 Anonymous "Human Rights-Theory and Practise" http://www.tamilnation.org (accessed 2006-05-03).

104 Vandewiele 5 


\section{African Charter on the Rights and Welfare of the Child ${ }^{105}$}

The African Charter which was inspired by the Convention on the Rights of the Child ${ }^{106}$ is the only legally binding treaty in the world which deals with children's rights in respect of international humanitarian law. ${ }^{107}$ The African Charter also provides greater protection to persons below the age of eighteen than the CRC does. ${ }^{108}$

This Charter was adopted by the African Union (or the Organisation of the African Union as it was referred to then) and came into force in November 1999. This Charter defines a child as anyone under the age of eighteen ${ }^{109}$ and compels State Parties to give primary consideration to what would be in the best interests of the child in all actions undertaken by any person or authority. ${ }^{110}$ Regard for the instruments of the International Labour Organisation is obliged ${ }^{111}$ and an entire article is devoted to the situation of children in armed conflicts. ${ }^{112}$

Article 22 states firstly that State Parties to this Charter should respect the IHL rules which are applicable in armed conflicts affecting the child. ${ }^{13}$

Secondly, Article 22 places the duty on State Parties to take all necessary measures to ensure that no child participates in hostilities directly, and to refrain from recruiting any child. ${ }^{114}$ The protection afforded in this Charter appears to provide the most protection for child soldiers.

Thirdly, State Parties to the Charter are obliged to take feasible measures to ensure the proper care and protection of children affected by any type of armed conflict, tensions or strife. ${ }^{115}$

The African Charter is the only regional Charter in the world which makes specific mention of child soldiers. ${ }^{116}$ The significance of this Charter internationally, lies in the fact that it has important repercussions for recognising that child soldiers have become a customary international law issue.

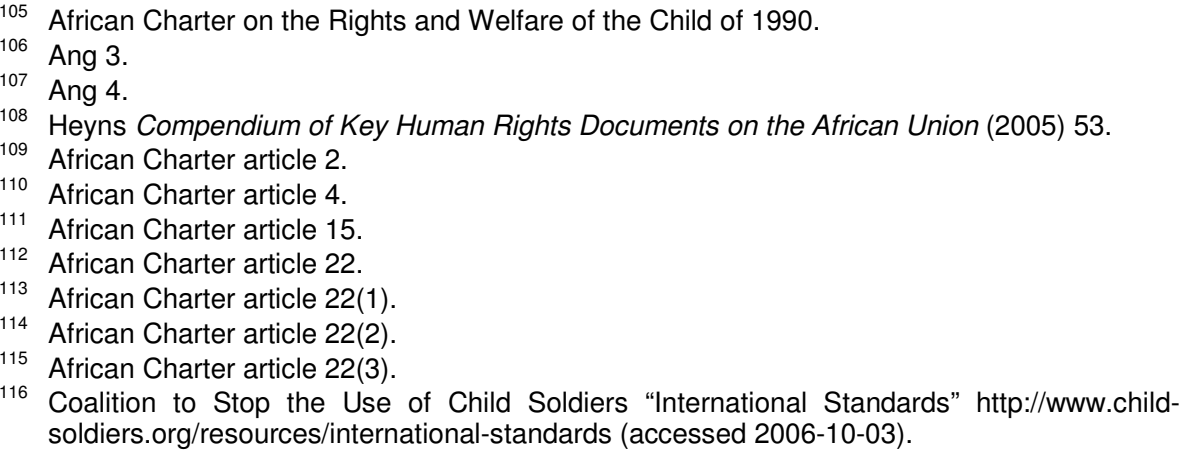


Apart from its importance internationally, the relevance of the Charter regionally is of great benefit to Africa in terms of legal progression and the creation of more stringent protection offered to African children.

\section{The United Nations Convention on the Worst Forms of Child Labour ${ }^{117}$}

In recalling the $\mathrm{CRC}$, the Governing body of the International Labour Committee $^{18}$ adopted the Convention on the Worst Forms of Child Labour, with the intention of eradicating child labour in its worst forms.

For purposes of this convention a child is regarded as any person below the age of eighteen. ${ }^{119}$ The applicability of this convention to the law surrounding the phenomenon of child combatants suggests that the very notion of child combatants is a form of child labour:

"For the purposes of this Convention, the term the worst forms of child labour comprises:

(a) all forms of slavery or practices similar to slavery, such as the sale and trafficking of children, debt bondage and serfdom and forced or compulsory labour, including forced or compulsory recruitment of children for use in armed conflict."

State Parties to this convention are obliged to provide for the effective enforcement and implementation of the provisions contained herein by imposing penal sanctions for breaches and non-compliance. ${ }^{121}$ Furthermore, State Parties are compelled under this convention to ensure the complete rehabilitation of the child who has been a victim of child labour in this regard. ${ }^{122}$

It is important to highlight that the age of eighteen is applied uniformly throughout the convention, thereby suggesting that forced or compulsory participation in armed conflict by anyone under such age is prohibited. Therefore, the incorporation of this convention into international law contradicts many of the pre-existing international laws pertaining to child combatants and can be viewed as aspiring for greater protection generally of child combatants.

117 United Nations Convention on the Worst Forms of Child Labour of 1999.

118 Convention on the Worst Forms of Child Labour Preamble and Sassoli How does Law Protect in War?: Vol I (2006)177.

119 Convention on the Worst Forms of Child Labour article 2.

120 Convention on the Worst Forms of Child Labour article 3(a).

121 Convention on the Worst Forms of Child Labour article 7(1).

122 Convention on the Worst Forms of Child Labour article 7(2). 


\section{The Rome Statute of the International Criminal Court $^{123}$}

The Rome Statute, albeit reactive in nature to the problems posed by the phenomenon of the child soldier, is of extreme importance and relevance to the position of the child soldier. The Rome Statute established an International Criminal court which has the power to exercise its jurisdiction over any person guilty of committing the crimes enlisted within the Statute. ${ }^{124}$ The relevance of the Rome Statute to the position of child combatants is that it regards either the conscription or the enlistment of children under the age of fifteen into armed forces or hostilities, as an active member, as a war crime. ${ }^{125}$ The meaning of the term "active" has been interpreted as meaning those military activities which are linked to combat. ${ }^{126}$

The Rome Statute imposes penile sanctions upon offenders of this Statute, ${ }^{127}$ thereby imposing necessary sanctions upon offenders, increasing the protection afforded to child combatants and attempting to limit the dire psychological and physical effects of armed conflict.

\section{The legal position of detained child combatants}

A detained child combatant has the status of a prisoner-of-war ${ }^{128}$ afforded to him if he is a party to an international armed conflict, under the Third Geneva Convention as well as under AP I. AP I states that children in an armed conflict who have not attained the age of fifteen, shall still benefit from the special protection afforded to children who have reached the age of fifteen as is evident in Article 77(3), where it states that:

"children who have not attained the age of fifteen years take a direct part in hostilities and fall into the power of an adverse Party, they shall continue to benefit from the special protection accorded by this Article [Article 77], whether or not they are prisoners of war.

In a non-international armed conflict, a detained child combatant will benefit from Common Article 3 to the Geneva Conventions, as well as from AP II generally. ${ }^{130}$

The ICRC delegates, when visiting detained children, aim to ensure that certain essentials are afforded to detained child combatants, and they try to obtain as a minimum that detained children are housed separately from

\footnotetext{
The Rome Statute of the International Criminal Court of 1998.

Rome Statute article 1.

25 Rome Statute article 8(2) (b) (xxvi) for an IAC;and article 8(2) (e) (vii) for an NIAC.

126 Coalition to Stop the Use of Child Soldiers "International Standards" http://www.childsoldiers.org/resources/international-standards (accessed 2006-10-03).

127 Rome Statute article 77.

128 The Geneva Conventions of August 121949.

129 AP I article 77(2).

130 Kuper Military Training and Children in Armed Conflict (2005)179.
} 
adults unless it is with family, ${ }^{131}$ direct, regular and frequent contact is maintained with family ${ }^{132}$ and food, medical care and hygiene are provided to cater for the child's needs and that the child continues with his schooling. ${ }^{133}$ It has been stated that children are far more vulnerable than adults are to the negative effects of imprisonment and it is for this reason that the detention of children should be avoided wherever possible. ${ }^{134}$

\section{Criminal liability of child soldiers}

Despite being afforded special protection in terms of international law, child soldiers are still criminally liable for their actions under international humanitarian law.

Protection is afforded to children who have engaged in hostilities by means of a prohibition of the imposition of the death penalty upon a child for war crimes committed by him if he had not attained the age of eighteen at the time that the crimes were committed. ${ }^{135}$

The criminal accountability of the child soldier poses a significant number of dilemmas. A number of international human rights organisations have objected to children younger than eighteen being held criminally accountable for their actions because they view prosecution as being detrimental to the rehabilitation of the child. ${ }^{136}$ The child soldier is often forced into joining the military and through the administration of drugs, the provision of incentives and continual threats to their lives; the child is turned into little more than a "killing-machine". The child combatant is deprived of his right to make decisions and yet, despite all of this, the child, if not disabled or killed, is still regarded as a perpetrator deserving of punishment. ${ }^{137}$ This view is reflective of a retributive approach to the establishment of accountability of the child, and one which is believed not to be well suited to the unique phenomenon of the child soldier. ${ }^{138}$

The dilemma comes to the fore when taking into consideration the fact that child soldiers are often responsible for some of the worst atrocities and breaches committed in armed conflicts and therefore under international

\footnotetext{
AP I article 77(2)

132 ICRC Publication "Child Soldiers" http://www.icrc.org/web/eng/siteeng0.nsf/htmlall/p0824? opendocument (accessed 2006-05-08).

133 Ibid.

134 Currie and De Waal The Bill of Rights Handbook (2005) 616.

135 AP I article $77(5)$.

136 Ogunfolu "The Use of Child Soldiers" 2005 International Conference on Human Rights in Africa, University of Johannesburg (unpublished paper).

137 Musila "Challenges in Establishing the Accountability of Child Soldiers for Human Rights Violations: Restorative Justice as an Option" 2005 African Human Rights LJ 321.

138 Ibid.
} 
law. ${ }^{139}$ In the case of Sierra Leone some of the worst atrocities documented, were committed at the hands of child combatants. ${ }^{140}$

The implication of this is that a child combatant is as much a victim as he is a perpetrator and the two conflicting viewpoints which exist in this regard, would be that of various NGOs and human rights organisations opposed to those of the victims of war, upon whom child combatants have committed atrocities.

The establishment of a Special Court for Sierra Leone saw the creation of the first international tribunal with the mandate to try children. ${ }^{141}$ However, it is interesting to note that there is no international instrument which expressly provides for the prosecution of children for international crimes ${ }^{142}$ and it is with this in mind that the Rome Statute is relevant.

The Rome Statute contains a specific provision which excludes the jurisdiction of the ICC when dealing with a child below the age of eighteen. ${ }^{143}$ The CRC also protects a child combatant charged with war crimes, by ensuring that the child be treated in a manner which is consistent with the promotion of the child's sense of dignity and worth, when being accused of infringements of the law. ${ }^{14}$

As a proposed remedy to this unsatisfactory position, it is suggested that an approach be adopted which meets the minimum standards of accountability, whilst taking into consideration the fact that child soldiers are themselves victims of armed conflict. ${ }^{145}$ The solution then lies both in the adoption of a restorative model which would ensure that the prosecution of children be guided by the imperative that rehabilitation programmes are not placed at risk ${ }^{146}$ and where necessary to prosecution, but with due regard being paid to the child's unique circumstances, age and level of maturity. Ultimately, the child's best interests ${ }^{147}$ should triumph in all situations, be that in the form of restorative justice or prosecution accompanied by the necessary rehabilitation.

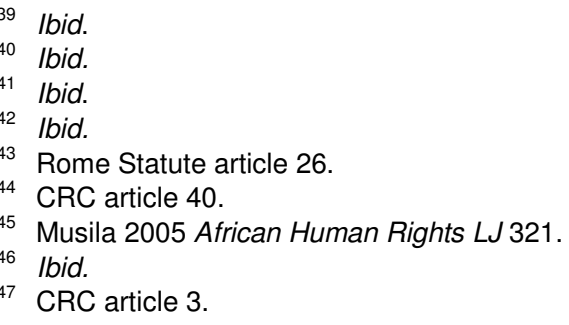




\section{CUSTOMARY INTERNATIONAL LAW}

\section{What is customary international law?}

Both customary international law and treaty law form a part of international law, the customary law constituting a large portion of IHL. ${ }^{148}$ Customary international law is derived from the general practices by States, which are deemed as being law ${ }^{149}$ and it is those rules in law which are not necessarily written. Customary international law can be found in official accounts of military operations and in a variety of other official documents, such as military manuals, case law and national legislation. ${ }^{150}$ It is important to note that until the actual codification of IHL, which started in 1864 with the adoption of the First Geneva Convention, custom was the main source of humanitarian law for a number of centuries. ${ }^{15}$

Customary International law is applicable to every State and no ratification needs to occur in order for it to be effective. A customary international law norm is recognised when both opinio iuris sive necessitatis and usus are present. $^{152}$ This means that for a rule to be regarded as customary international law, both a settled practice must occur and the obligation to be bound in terms of that law must be accepted by the State. ${ }^{153}$

A recent study, undertaken by the ICRC on which rules exactly of international humanitarian law form part of customary international law, found that a number of the rules and principles contained within IHL, do in fact exist under customary law. ${ }^{154}$

\section{Relevance and advantages of customary international law}

Customary law is relevant in filling in the gaps created in respect of the protection afforded to child combatants. ${ }^{155}$ These gaps in the law exist either because of the non-ratification by States of the relevant treaties or from the insufficient rules pertaining to non-international armed conflicts. ${ }^{156}$ For our purposes, the lack of ratification of the relevant treaties is where potential gaps lie.

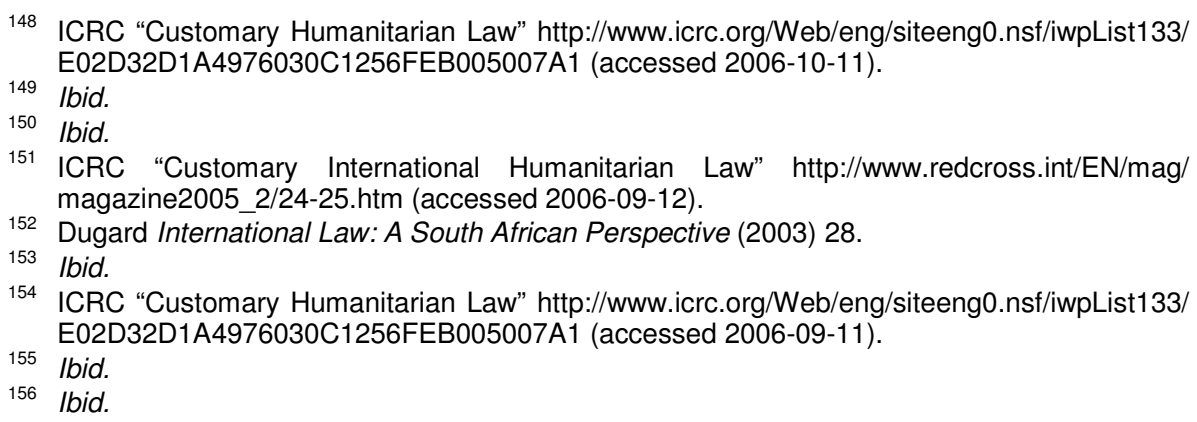


Therefore, the advantage to customary international law lies in the fact that a State does not need to expressly ratify it in order to be bound by it. A State will simply be bound in terms of customary law if the State practice, to which the rule relates, is "widespread, representative and virtually uniform"157 and it has been accepted as such by the law. ${ }^{158}$

The importance then of customary international law for child combatants is that it will act as the law upon which to fall back upon when treaty law is insufficient. This will ensure that child combatants receive full protection under international law.

\section{The Prosecutor $v$ Norman, Fofana and Kondewa ${ }^{159}$}

The recent case, tried in the International Criminal Court has had drastic implications for the recognition of child combatants in customary international law. The importance of the CDF case lies in its outcome.

Sam Hinga Norman, minister in the Sierra Leone government and the national co-ordinator of the Civil Defence Force, ${ }^{160}$ was accused on 07 March 2003 of committing war crimes based on the conscription and enlistment of children into armed forces and groups, who were below the age of fifteen as well as for their direct participation in the hostilities. ${ }^{161}$ Norman contested his indictment based on the fact that the use of child soldiers under the age of fifteen was not regarded as a war crime and that it had only been regarded as such upon the enactment of the 1998 Rome Statute. Norman therefore refuted criminal liability in this regard, citing that the recruitment of children before 1996 was not regarded as a crime.

The ICC, however, found Norman guilty of committing a war crime. It was held that the prohibition on the recruitment and participation of child soldiers under the age of fifteen in armed conflicts was in fact regarded as a customary norm:

"Prior to November 1996, the prohibition on child recruitment had crystallised as customary international law, as demonstrated by the widespread recognition and acceptance of the norm prohibiting child recruitment in these international instruments, reiterated in the 1990 African Charter on the Rights and Welfare of the Child." abbreviation for Civil Defence Force.

160 ICC "The Head Heeb: Punishment Without Crime" http://www.blogmosis.com/archives/ 025340.html (accessed 2006-05-12).

161 Copy of Indictment against Sam Hinga Norman "Special Court for Sierra Leone" http://www.sc-sl.org/normanindictment.html (accessed 2006-05-12).

162 ICC "The Head Heeb: Punishment Without Crime" http://www.blogmosis.com/archives/ 025340.html (accessed 2006-05-12).
} 
It was held further that the enactment of the 1998 Rome Statute for the ICC was intended for the purpose of codifying the customary norms that already existed, as opposed to creating a new norm. ${ }^{163}$

The decision yielded by this case is somewhat problematic in its application in respect of international law. The minority judgment in the CDF case, made by well-renowned human rights activist, Judge Robertson, opposed the stance adopted by the majority decision taken in this case. ${ }^{164}$

Justice Robertson pointed out that the decision to regard the recruitment of children under the age of fifteen as a war crime deprived the accused of his right to the principle of nulla poena sine lege ${ }^{165}$ and the principle of nulla poena sine praevia lege poenali, meaning that "no punishment (may be inflicted) without a penal enactment preceding (the crime)."166 Justice Robertson traced the development of the relevant treaty law and found that the Rome Statute was a "landmark in international criminal law"167 and that with its adoption the recruitment of children under the age of fifteen was regarded as a crime, and not before its enactment. ${ }^{168}$

It has been submitted that prosecution based on "vaguely defined "customary norms"'169 would ensure that a defendant only be aware of his crimes when being indicted. ${ }^{170}$ It was stated in a commentary to the ICC judgment that:

"Recruiting child soldiers is an affront to any civilized person, but it was not a crime until 1998, and in their [the ICCR] zeal to punish the abuses of the Sierra Leone conflict, the panel has dangerously extended the reach of international penal law."

For the child combatant, however, the judgment in the CDF case beckons a favourable dispensation, guaranteeing as a minimum that a certain standard of protection will be administered.

\section{ENFORCEMENT AND RECOMMENDATIONS}

\section{Implementation of international humanitarian law}

The enforcement of IHL principles lies firstly within the State. The State, upon ratifying relevant international treaties, must still implement the

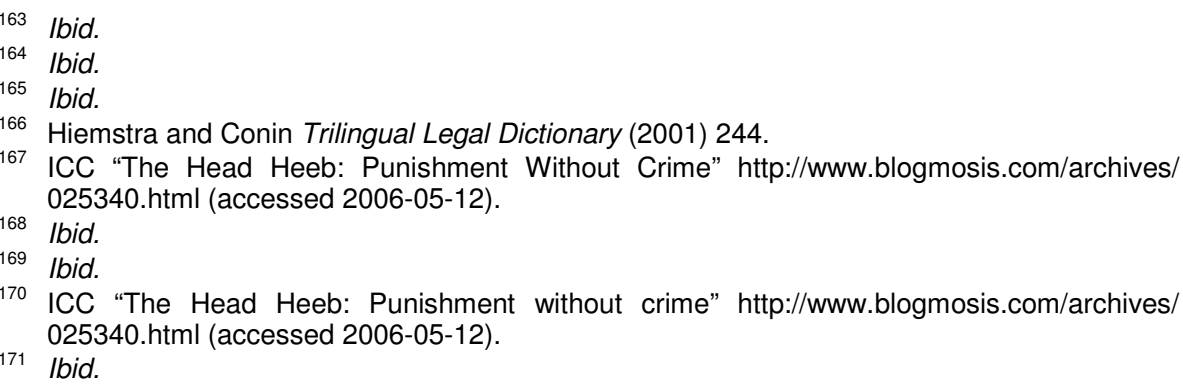


provisions of those laws into municipal law in order that they are not merely applied indirectly. ${ }^{172}$ Once these laws have been implemented into municipal law they are directly applied and enjoy the same level of respect afforded to municipally enacted law. However, the mere enactment of these laws into municipal law does not always provide satisfactorily for their effective enforcement. The enforcement of $\mathrm{IHL}$ principles is to a large extent championed by non-governmental organisations (NGOs) and humanitarian bodies.

\section{The role played by non-governmental organisations and humanitarian bodies in the enforcement of IHL}

The role played by NGO's and humanitarian bodies is a crucial one as their mission guarantees the effective implementation of $\mathrm{IHL}$ principles and ensures that dissemination of the applicable IHL principles occur. There are various organisations such as the International Committee of the Red Cross in particular which have effected huge efforts to ensure the protection of child combatants.

\section{The International Committee of the Red Cross}

The ICRC's fundamental purpose is to offer protection and assistance to both civilian and military victims of war and internal violence. ${ }^{173}$ The ICRC receives its mandate from the State Parties to both the Geneva Conventions and to the Additional Protocols of $1977^{174}$ and it aspires to prevent suffering through the promotion of compliance with IHL.

The ICRC ensures that special protection is afforded to children as it recognises that children require extra protection based on their particularly vulnerable status. ${ }^{175}$ The ICRC, as the guardians of IHL, has a responsibility to not only uphold IHL, but also to develop it and disseminate knowledge of international humanitarian law standards. ${ }^{17}$

The role played by the ICRC in the practical enforcement of the law in regard to the child combatant and in the dissemination of the law is vital. The ICRC and various international human rights organisations have obviously contributed the most significantly to the phenomenon, by ensuring that the plight of the child combatant does not go unheard of.

There are also various bodies which have been set up with the primary intention of rehabilitating and facilitating children who have been victims of

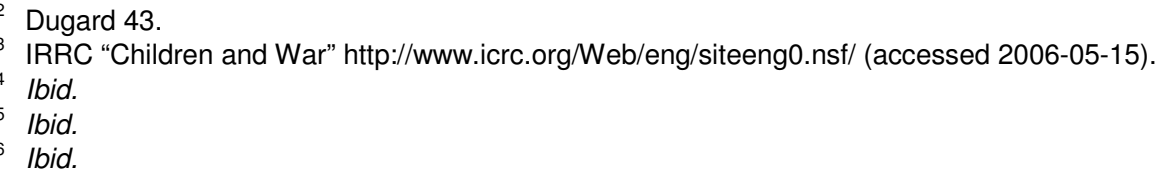


war, one of which is Save the Children, ${ }^{177}$ an American Organisation assisting with:

"any emergency that puts at great risk the survival, protection, and well-being of significant numbers of children, where addressing the needs and well-being of those children is beyond the indigenous coping capacity, and where Save the Children is able to mobilize the financial and human resources to take urgent action on their behalf."

The ICRC and various international human rights organisations, such as UNICEF, ${ }^{179}$ SOS Children's Villages, inter alia have obviously contributed the most significantly to this phenomenon.

\section{Practical assistance rendered by the ICRC}

The assistance rendered by the ICRC ensures that the IHL principles are practically implemented. The ICRC ensures that relief and humanity prevail in conditions of war by affording victims their basic human rights. The practical effect of this ensures that the child combatant receives greater protection from the effects of war, thereby ensuring that $\mathrm{IHL}$ is not just paper law. The following are a few of the ways in which the ICRC renders its assistance: $:^{180}$

- The protection of unaccompanied minors occurs, which includes identification of children and reuniting them with family or next-of-kin;

- long term assistance includes tracing missing persons and advancing respect for the right to education;

- the conditions of children detained are monitored and the separation of children from adults and the separation between boys and girls are encouraged. Continued efforts are made to bring about the release of detained children; and

- aid in the form of food, clothing and the construction of shelter is given in times of emergencies. The provision of health care, health maintenance, first aid and feeding programmes inter alia are also provided. ${ }^{181}$

\section{Recommendations by the ICRC}

The plight of the child combatant poses a number of problems and despite near-universal condemnation of the use of child combatants, ${ }^{182}$ this

\footnotetext{
177 "Save the Children: Emergencies and Protection" http://ga4.org/savethechildren/join.tcl (accessed 2006-05-08).

178 lbid.

179 UNICEF is an abbreviation for the United Nations International Child Emergency Relief Fund.

180 IRRC "Children and War" http://www.icrc.org/Web/eng/siteeng0.nsf/ (accessed 2006-05-15).

181 Ibid.

182 Kelso "Child Soldiers Global Report 2004" 13 http://www.child-soldiers.org/document get.php?id=740 (accessed 2006-10-04).
} 
phenomenon is still prevalent. It is with this in mind that various organisations (the ICRC in particular) have proposed a number of recommendations. The proposal of such recommendations is hoped to achieve a situation in which the position pertaining to the child is one that provides him with the maximum protection and ensures that his best interests are catered for too.

The ICRC has undertaken and committed itself in a number of resolutions to promote and protect the rights of children. Every four years an International Conference is held, which brings together representatives of the various components of the ICRC as well as State Parties to the Geneva Conventions to discuss humanitarian matters which are of particular concern. The $26^{\text {th }}$ International Conference was held at Geneva in December 1995, and it was at this conference that a resolution was adopted, detailing the proposed plan to be used in respect of child combatants.

The Resolutions adopted entailed two recommendations: ${ }^{184}$

- Parties to conflict should refrain from "arming" children under the age of eighteen and such Parties should take all feasible steps to ensure that children younger than eighteen do not take a direct part in hostilities; and

- States, the ICRC and other "competent entities and Organisations" are encouraged to develop preventative and protective measures which would ensure that victims of armed conflict receive medical, psychological and social assistance by personnel qualified to do so.

The recommendations thereby serve to promote the principle of nonrecruitment and non-participation in armed conflicts by children younger than eighteen, as well as ensuring that concrete action be taken to assist child victims of combat. It has been said that the various components of the ICRC strive "unanimously and actively" ${ }^{185}$ to promote eighteen as the universal age limit for participation in armed conflict in any form whatsoever by children.

These recommendations, which were made at the International Conference, have been reiterated in a number of academic articles and journals. ${ }^{187}$ The idea of raising the age for either direct involvement or participation in hostilities to an absolute minimum of eighteen years old has found favour with a number of authors dealing with this matter.

In a study conducted on behalf of the Henry Dunant Institute, undertaken by Guy Goodwin-Gill and Ilene Cohn, ${ }^{188}$ it was suggested that a total ban on

${ }^{83}$ IRRC "Children and War" http://www.icrc.org/Web/eng/siteeng0.nsf/ (accessed 2006-05-15). 84 Ibid.

185 Anonymous "Children and War" 2001 IRRC 1163-1173. Children and war http://www. icrc.org/Web/eng/siteeng0.nsf/ (accessed 2006-05-15).

186 Ibid.

187 Goodwin-Gill and Cohn are just two authors of many who have shown support for the recommendations posed by the ICRC.

188 Ventre "Books and reviews: "Child soldiers: The Role of Children in Armed Conflicts" http://www.icrc.org/Web/eng/siteeng0.nst/iwpList148/C15EE5318666535BC1256B6600598 386 (accessed 2006-05-03). 
the participation of children under the age of eighteen is an objective which should be obtained in years to come. Their suggestion for raising the minimum age of recruitment would take place through the adoption of a declaration containing the minimum humanitarian standards and banning any participation whatsoever of children under the age of eighteen from taking part in armed conflict. The Declaration would further specify the responsibilities of adults in charge of the recruitment of children.

It is clear that an imposition of eighteen as the absolute minimum age for participation in hostilities would be in the best interests of the child. The psychological and physical effects created by participation in armed conflict would be limited greatly. This is surely the position that all countries should be striving towards - a world where the very basic rights of the child are protected.

\section{CONCLUSION}

As a specially protected category of persons, children do enjoy a number of rights. Over 25 articles in both the Geneva Conventions and the Additional Protocols specifically concern children, ${ }^{190}$ not to mention numerous other international instruments which provide specific protection to the child combatant. The question, however, which comes to the fore is one which queries whether or not the child combatant is protected sufficiently and in a manner which is consistent with the best interests of the child.

The overall legal position pertaining to the child soldiers, once all of the relevant legal instruments have been considered, is contradictory and one which creates a fair amount of legal uncertainty. This legal uncertainty is illustrated very basically when summarising the age restrictions stipulated in the applicable legal instruments. The age restrictions stipulated for the prohibition of participation or recruitment into armed conflict are either fifteen, ${ }^{191}$ sixteen ${ }^{192}$ and in some instances eighteen. ${ }^{193}$

Fifteen is the age regarded by most international instruments as being the minimum age at which direct participation in armed conflict is prohibited. The imposition of fifteen as the minimum age requirement came about through the common belief that fifteen and sixteen year-old children were often better equipped to fight than grown men were, ${ }^{194}$ presumably because of their assumed higher energy levels and athletic ability. This appears to be an arbitrary imposition of an age limit as the psychological and physical consequences of armed conflict on a child, as illustrated through their

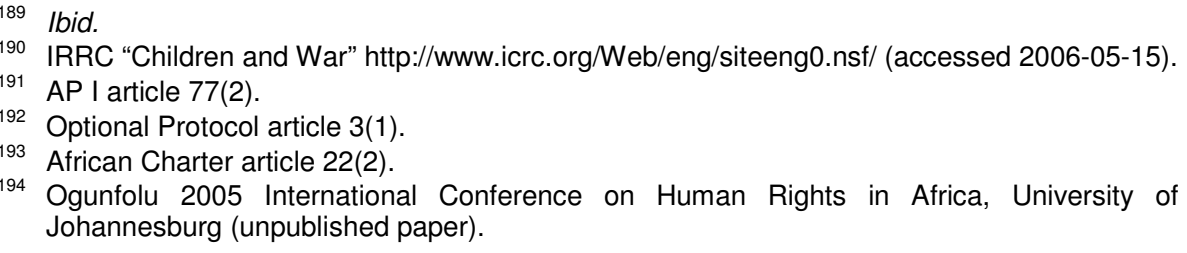


numerous recollections of war, are dire and were clearly not taken into account.

The protection afforded to child soldiers pales in comparison to the consequences that war imposes on them. The numerous investigations undertaken and reports compiled on the plight of the child soldier consistently highlight the devastating effects of armed conflict on a child. Psychological evaluations of the impact that a war has on a child have revealed that a large majority of children exposed to war, encounter dead and severely mutilated bodies, leaving many of them with a constant fear for their own death. ${ }^{195}$ This study, coupled with the various accounts recalled by child soldiers, suggests that the psychological and physical impacts of war on a child combatant are in fact devastating.

The participation of children in armed conflict is not only of dire consequence to the child, but it appears to allow a further and uncontrolled element of irrationality onto the battlefield. The effects of drugs, alcohol and a deep-seated fear for their own death cause a greater threat to be posed to both civilians and other combatants alike by the child combatant because the immature and impulsive conduct of a child endangers the lives of everyone around him. ${ }^{196}$ It is therefore evident that the use of child soldiers in armed conflict has a negative impact on both the child and the society at large and is obviously not in the best interests of the child ultimately.

The implementation of the law in regard to the child soldier also appears to lack an element of certainty. The ratification of international instruments aimed at the protection of the child soldier, ensures that a number of countries get the opportunity to express their condemnation of the use of child soldiers, but in reality this condemnation often amounts to little more than paper law as the actual implementation of the law into municipal law often does not occur, thereby ensuring that the law pertaining to the child soldier does not enjoy direct application. The fact that there is not always, and very often not a connection at all between international law and enforcement, suggests that further measures need to be implemented in order to protect child soldiers and guard against their use. This should include measures taken to mitigate the psychological and physical harm inflicted upon a child.

It is therefore clear that the law regarding the child soldier does not satisfactorily protect the child and his best interests.

The continued efforts of NGOs and other such organisations do strive for a position in which the implementation of IHL is carried out effectively, but their efforts cannot remedy the situation in its entirety.

The proposals to regard eighteen as the absolute minimum age for participation and recruitment into armed conflict appear to cater most

195 "Effect of War on Children" http://www.ppu.org.uk/chidren/children_effect_yugo.html (accessed 2006-09-17).

196 IRRC "Children and War" http://www.icrc.org/Web/eng/siteeng0.nsf/ (accessed 2006-05-15). 
proficiently of the best interests of the child and the imposition of international sanctions on countries violating this norm appears to be an adequate way in which to compel compliance with the relevant laws.

Graça Machel is quoted as saying: ${ }^{197}$ "War violates every right of a child the right to life, the right to be with family and nurtured and respected," and in light of this it is hoped that as an international community we will recognise that a problem does exist, and then vigorously fight to solve it. The continued dissemination of the plight of the child combatant will ensure that the best interests of the child are given effect, ultimately envisaging that they are left out of war completely.

97 SOS Children Link "Children in Conflict:Child Soldiers" http://child-soldier.org/ (accessed 2006-09-17). 